University of Nebraska - Lincoln

DigitalCommons@University of Nebraska - Lincoln

Faculty Papers and Publications in Animal

Science

Animal Science Department

1975

\title{
Effects of Source on Copper Uptake by Swine
}

\author{
G. L. Zoubek \\ Win Butler University \\ E. R. Peo, Jr. \\ University of Nebraska-Lincoln \\ B. D. Moser \\ University of Nebraska-Lincoln \\ T. Stahly \\ University of Nebraska-Lincoln \\ P. J. Cunningham \\ University of Nebraska-Lincoln
}

Follow this and additional works at: https://digitalcommons.unl.edu/animalscifacpub

Part of the Animal Sciences Commons

Zoubek, G. L.; Peo, Jr., E. R.; Moser, B. D.; Stahly, T.; and Cunningham, P. J., "Effects of Source on Copper Uptake by Swine" (1975). Faculty Papers and Publications in Animal Science. 641.

https://digitalcommons.unl.edu/animalscifacpub/641

This Article is brought to you for free and open access by the Animal Science Department at DigitalCommons@University of Nebraska - Lincoln. It has been accepted for inclusion in Faculty Papers and Publications in Animal Science by an authorized administrator of DigitalCommons@University of Nebraska - Lincoln. 


\title{
EFFECTS OF SOURCE ON COPPER UPTAKE BY SWINE ${ }^{1}$
}

\author{
G. L. Zoubek ${ }^{2}$, E. R. Peo, Jr., B. D. Moser, \\ T. Stahly and P. J. Cunningham
}

University of Nebraska, Lincoln ${ }^{3} 68503$

\begin{abstract}
Summary
Four catheterized crossbred $(\mathrm{Y} \times \mathrm{H})$ barrows were used in a $4 \times 4$ latin square arrangement of treatments in a completely randomized block design, to determine the effect of source on copper uptake as determined by serum $\mathrm{Cu}$ concentration changes over a 7.5-hr sampling period. Dietary treatments were: (A) basal with no added $\mathrm{Cu}$, (B) basal + $5.2 \mathrm{mg} \mathrm{Cu}$ (from $\mathrm{CuSO}_{4}$ ) $/ \mathrm{kg}$ of diet, (C) basal + $5.2 \mathrm{mg} \mathrm{Cu}$ (EDTA chelated $\mathrm{Cu}) / \mathrm{kg}$ of diet, and (D) basal $+5.2 \mathrm{mg} \mathrm{Cu}$ (from $\mathrm{CuSO}_{4}$ ) $+34.1 \mathrm{mg}$ ethylene diamine tetra acetic acid (EDTA)/kilogram of diet. Animals were placed on the semi-purified basal diet for 5 days, fasted for 1 day and then given their dietary treatment. Following consumption of the dietary treatment, blood samples were collected from each animal at $15-\mathrm{min}$ intervals for $3.0 \mathrm{hr}$ and at 1.5 -hr intervals over the remaining $4.5 \mathrm{hr}$ of a $7.5 \mathrm{hr}$ sampling period. The samples were collected via jugular catheters and during the 4-week trial each animal was exposed to all dietary treatments. Serum $\mathrm{Cu}$ concentration was not significantly $(\mathrm{P}<.05)$ affected by dietary treatment. However serum $\mathrm{Cu}$ concentrations did change significantly $(P<.05)$ during the 7.5 -hr sampling period. A significant

\footnotetext{
'Published with the approval of the Director as Paper No. 3846, Journal Series, Nebr. Agr. Exp. Sta. Research reported was conducted under Project 13-22.

${ }^{2}$ Current address County Extension Agent, Holt County, O'Neill, Nebraska 68763.

${ }^{3}$ Department of Animal Science. Acknowledgement is made to John Welch and Larry McMulen for their assistance with the conduct of the experiment and development of certain laboratory procedures.
}

$(\mathrm{P}<.01)$ animal $\mathrm{x}$ sampling time interaction was also observed. The results indicate that prechelated $\mathrm{Cu}$ or dietary additions of EDTA had little influence on the efficiency of $\mathrm{Cu}$ uptake by swine. Sampling time following consumption of a diet was important as evident from the reflected changes in serum $\mathrm{Cu}$ concentration.

\section{Introduction}

Numerous studies have shown that levels to $250 \mathrm{ppm}$ added dietary $\mathrm{Cu}$ have improved gains and feed conversion of growing pigs. These favorable results have been reported by Barber et al. (1955), Hawbaker et al. (1961), Braude (1965), Wallace (1967), Castell and Bowland (1968), the N.R.C.42 Committee on Swine Nutrition (1970); Kline et al. (1972). However when high levels of $\mathrm{Cu}$ are fed, liver $\mathrm{Cu}$ concentrations are greatly increased as reported by DeGoey et al. (1971), Kline et al. (1971) and Gipp et al. (1973).

Chelation has been suggested as a method to improve utilization of trace minerals by animals. Davis et al. (1962) observed that when chicks were fed diets deficient in $\mathrm{Cu}$ but supplemented with EDTA, the EDTA reduced the chicks' requirements or increased the availability of $\mathrm{Cu}$, thus preventing $\mathrm{Cu}$ deficiency.

The purpose of the research reported herein was to determine the effect of source of copper and a chelating agent on copper uptake by growing swine.

\section{Materials and Methods}

Four crossbred $(\mathrm{Y} \times \mathrm{H})$ barrows weighing 
approximately $28 \mathrm{~kg}$ were used in a $4 \times 4$ latin square arrangement of treatments in a completely randomized block designed experiment. The animals were housed individually in an environmentally regulated swine research unit. The walls and two thirds of the floor were of concrete structure with a front gate made of galvanized metal. The remainder of the floor area consisted of a $25.4 \mathrm{~mm}$ wide galvanized metal grid. The pigs were watered ad libitum from automatic drinking fountains (water analyzed $1.3 \mathrm{mcg} / \mathrm{ml} \mathrm{Cu}$ ) and received their diets from galvanized metal feeders. The pigs were weighed weekly and fed a daily ration (5\% of body weight ${ }^{9}$ ) every morning at 8:00 am. This ration furnished enough energy for $.24 \mathrm{~kg}$ of gain per day during the 28-day trial.

A semi-purified $14 \%$ protein diet (composition, table 1) was used for all treatments. The experimental dietary treatments were as follows: (A) Basal with no added $\mathrm{Cu}$; (B) Basal plus $5.2 \mathrm{mg} \mathrm{Cu}\left(\mathrm{CuSO}_{4}\right) / \mathrm{kg}$ of $\mathrm{diet}^{4}$; (C) Basal plus $5.2 \mathrm{mg} \mathrm{Cu}$ (pre-chelated $\mathrm{Cu}$ ) $/ \mathrm{kg}$ of $\operatorname{diet}^{5}$; and (D) Basal plus $5.2 \mathrm{mg} \mathrm{Cu}\left(\mathrm{CuSO}_{4}\right)$ and $34.1 \mathrm{mg}$ EDTA $/ \mathrm{kg}$ of diet. ${ }^{6}$

Since the objectives of this experiment required frequent blood sampling, a catheter was surgically inserted into the jugular vein as described by Zimmerman et al. (1973). After 10 to 14 days of recovery, the animals were considered ready for frequent blood sampling with hopefully no stress to the animal.

All of the pigs were placed on the basal diet (A) 5 days prior to the first blood sampling and fasted 1 day prior to the initial treatment sampling. The purpose of fasting was to initiate immediate consumption of the allotted feed following which blood samples were to be taken. As each pig was given its experimental diet (A, B, C, or D), $5 \mathrm{mls}$ of blood was removed with subsequent samples taken at

\footnotetext{
${ }^{4}$ The basal diet analyzed $4.8 \mathrm{mg} \mathrm{Cu} / \mathrm{kg}$ of diet. The NRC suggested levels of $\mathrm{Cu}$ for growing swine is $10 \mathrm{mg}$ $\mathrm{Cu} / \mathrm{kg}$ of diet, so $5.2 \mathrm{mg} \mathrm{Cu}$ was added $/ \mathrm{kg}$ of diet.

${ }^{5}$ Sequestrene $\mathrm{Na}_{2} \mathrm{Cu}$ Copper Chelate. Geigy Agricultural Chemicals, Ardsley, New York.

${ }^{6}$ (Ethylene dinitrilo)-tetra acetic acid tetra sodium salt. Matheson Coleman Bell Manufacturing Chemists, Norwood, Ohio. Based on previous work at the station by $A$. Owen, a molar ratio of $1: 1$ for EDTA: total Cu was used.
}

15 -min intervals for the initial $3.0 \mathrm{hr}$ and at 1.5 $\mathrm{hr}$ intervals for the following $4.5 \mathrm{-hr}$ of a $7.5 \mathrm{hr}$ collection period. The pigs were then returned to diet $\mathrm{A}$ which contained no added $\mathrm{Cu}$ for 5 days and the procedure described above repeated until each animal had been exposed to each of the four experimental diets.

The blood samples were allowed to coagulate and were then centrifuged at 2,000 RPM for 10 minutes. The serum was transferred to a clean plastic test tube and frozen until analyzed for copper. The serum samples were allowed to thaw and were prepared for analysis using the procedure outlined by Olson and Hamlin (1968). The samples were analyzed for $\mathrm{Cu}$ by atomic absorption spectroscopy by procedures outlined by Perkin-Elmer (1971).

Since blood samples were collected frequently from the experimental animals, samples were also obtained at random intervals to determine if changes in hemoglobin levels and packed cell volume (PCV) occurred due to frequency of sampling. PCV were determined by the microcentrifuge technique described by Merck (1966) and hemoglobin levels were measured by the cyanomethemoglobin method.

TABLE 1. COMPOSITION OF BASAL DIETa

\begin{tabular}{llc}
\hline \hline Ingredient & Ref. no. & G/kg of Diet \\
\hline $\begin{array}{l}\text { Corn, starch, dehy. } \\
\text { grnd }\end{array}$ & $4-02-889$ & 604.3 \\
$\begin{array}{l}\text { Cattle, Casein } \\
\quad \text { (vit.-free) }\end{array}$ & $5-01-162$ & 148.6 \\
$\begin{array}{l}\text { Sugar cane, sugar } \\
\text { Corn, yellow, }\end{array}$ & $4-04-701$ & 100.0 \\
$\quad$ grain grnd & $4-02-992$ & 50.0 \\
$\begin{array}{l}\text { Swine, lard } \\
\text { Calcium phosphate }\end{array}$ & $4-04-790$ & 30.0 \\
$\quad$ dibasic, commer- & & \\
$\quad$ cial & $6-01-080$ & 22.1 \\
$\begin{array}{l}\text { Mineral premixb } \\
\text { Vitamin premix c }\end{array}$ & & 20.0 \\
Salt, NaCl, Com- & & 20.0 \\
$\quad$ mercial (iodized) & $6-04-152$ & 5.0 \\
\hline
\end{tabular}

${ }^{a}$ Calculated composition: protein, $14 \%, \mathrm{Ca}, .65 \%$ and $P, .50 \%$.

bMineral addition $/ \mathrm{kg}$ of diet: iron, $100 \mathrm{mg}$; magnesium, $400 \mathrm{mg}$; manganese, $20 \mathrm{mg}$; and zinc, 50 milligrams.

cVitamin addition $/ \mathrm{kg}$ of diet: vitamin $\mathrm{A}, 2,600 \mathrm{IU}$; vitamin D, 250 IU; choline chloride, $400 \mathrm{mg}$; panthothenic acid, $22 \mathrm{mg}$; niacin, $20 \mathrm{mg}$; vitamin $\mathrm{K}$, $4.4 \mathrm{mg}$; riboflavin, $2.4 \mathrm{mg}$; thiamine, $2.2 \mathrm{mg}$; pyridoxine, $2.2 \mathrm{mg}$; and vitamin $B_{12}, .022$ milligrams. 
TABLE 2. EFFECT OF SOURCE OF DIETARY COPPER ON SERUM Cu CONCENTRATION MEASURED OVER 7.5 HR POST FEEDING OF PIGS PREVIOUSLY FASTED FOR 1 DAY a

\begin{tabular}{|c|c|c|c|c|}
\hline \multirow{3}{*}{ Sample time } & \multicolumn{4}{|c|}{ Dietary treatmentsb,c } \\
\hline & $\underline{\mathrm{A}}$ & $\underline{B}$ & $\underline{\mathrm{C}}$ & $\underline{\mathrm{D}}$ \\
\hline & $\begin{array}{l}\text { basal with } \\
\text { no added } \mathrm{Cu}\end{array}$ & 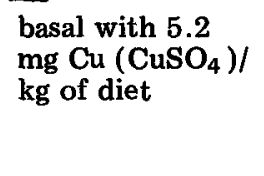 & $\begin{array}{l}\text { basal plus } \\
5.2 \mathrm{mg} \mathrm{Cu} \\
\text { (chelated } \mathrm{Cu} \text { )/ } \\
\text { kg of diet }\end{array}$ & $\begin{array}{l}\text { basal plus } \\
5.2 \mathrm{mg} \mathrm{Cu} \\
\left(\mathrm{CuSO}_{4}\right) \text { and } \\
34.1 \mathrm{mg} \text { EDTA } \\
\mathrm{kg} \text { of diet }\end{array}$ \\
\hline & \multicolumn{4}{|c|}{ Serum $\mathrm{Cu}, \mathrm{mcg} / \mathrm{ml}$} \\
\hline $\begin{array}{l}\quad \text { Initial } \\
15 \mathrm{~min} \\
30 \mathrm{~min} \\
45 \mathrm{~min} \\
1 \mathrm{hr} 00 \mathrm{~min} \\
1 \mathrm{hr} 15 \mathrm{~min} \\
1 \mathrm{hr} 30 \mathrm{~min} \\
1 \mathrm{hr} 45 \mathrm{~min} \\
2 \mathrm{hr} 00 \mathrm{~min} \\
2 \mathrm{hr} 15 \mathrm{~min} \\
2 \mathrm{hr} 30 \mathrm{~min} \\
2 \mathrm{hr} 45 \mathrm{~min} \\
3 \mathrm{hr} 00 \mathrm{~min} \\
4 \mathrm{hr} 30 \mathrm{~min} \\
6 \mathrm{hr} 00 \mathrm{~min} \\
7 \mathrm{hr} 30 \mathrm{~min}\end{array}$ & $\begin{array}{l}2.36 \\
2.27 \\
2.45 \\
2.25 \\
2.33 \\
2.32 \\
2.34 \\
2.35 \\
2.18 \\
2.43 \\
2.41 \\
2.53 \\
2.71 \\
2.69 \\
2.58 \\
2.43\end{array}$ & $\begin{array}{l}2.63 \\
2.41 \\
2.55 \\
2.22 \\
2.23 \\
2.34 \\
2.39 \\
2.53 \\
2.31 \\
2.35 \\
2.37 \\
2.42 \\
2.53 \\
2.38 \\
2.37 \\
2.37\end{array}$ & $\begin{array}{l}2.44 \\
2.43 \\
2.35 \\
2.34 \\
2.35 \\
2.40 \\
2.38 \\
2.44 \\
2.33 \\
2.37 \\
2.41 \\
2.41 \\
2.55 \\
2.45 \\
2.47 \\
2.46\end{array}$ & $\begin{array}{l}2.46 \\
2.57 \\
2.56 \\
2.60 \\
2.39 \\
2.19 \\
2.28 \\
2.54 \\
2.36 \\
2.32 \\
2.32 \\
2.56 \\
2.49 \\
2.47 \\
2.50 \\
2.48\end{array}$ \\
\hline
\end{tabular}

aValues represent mean of four animals/trt.

bifference due to sampling time significant $(P<.05)$.

cSampling time $x$ animal interaction significant $(P<.01)$.
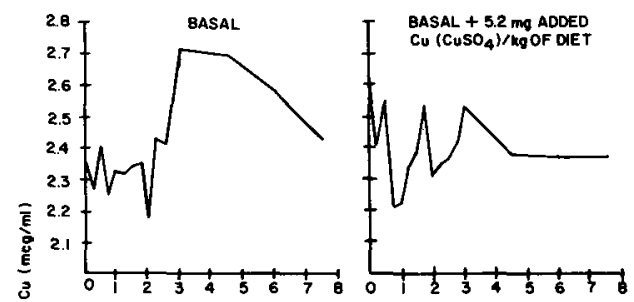

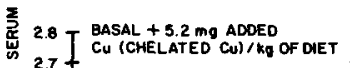

BASAL + $5.2 \mathrm{mg} A D O E D$ Cu (CuSO 4$) / \mathrm{kg}$ OF OIET EDTA IN AN EOUAL MOLAR

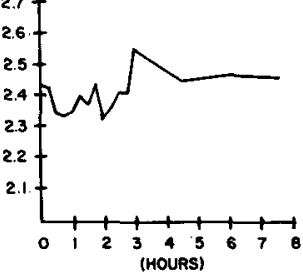
RATIO TO TOTAL COPPER

Figure 1. Effect of dietary $\mathrm{Cu}$ source on blood serum $\mathrm{Cu}$ concentration measured over $7.5 \mathrm{hr}$ post feeding of pigs previously fasted for 1 day.
Analyses of variance of the data were conducted as outlined in Steele and Torrie (1960).

\section{Results and Discussion}

The results of dietary $\mathrm{Cu}$ source on blood serum $\mathrm{Cu}$ levels following the consumption of a diet containing known concentrations and sources of $\mathrm{Cu}$ by fasted animals are summarized in table 2. The changes in serum $\mathrm{Cu}$ concentration are graphically shown in figure 1 . No significant differences due to dietary treatment were observed but serum $\mathrm{Cu}$ concentrations appeared to be less variable on the average in pigs fed chelated $\mathrm{Cu}$.

There was a significant $(P<.05)$ difference in serum $\mathrm{Cu}$ concentration due to sampling time. Serum $\mathrm{Cu}$ concentration tended to decrease consistently across treatments during the first $2.0 \mathrm{hr}$ of sampling, then increased and reached a peak at $3.0 \mathrm{hr}$ and then tended to plateau near initial levels over the remaining 4.5 


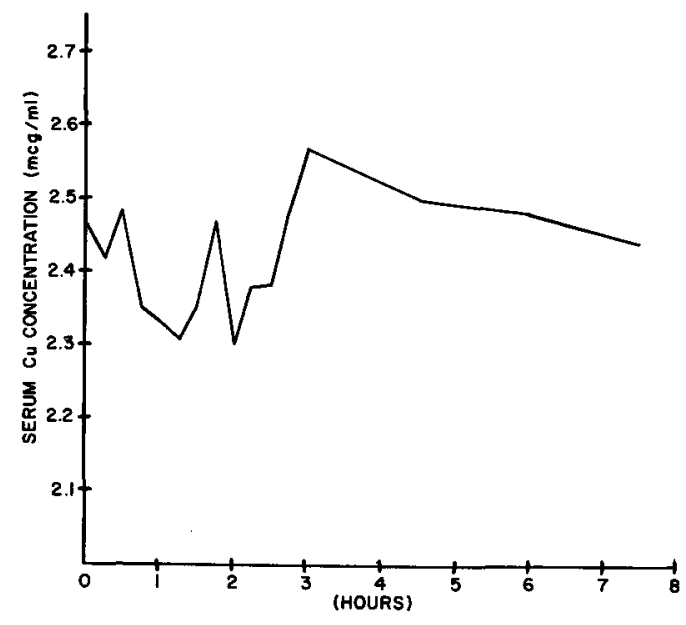

Figure 2. Mean serum $\mathrm{Cu}$ concentration changes measured over $7.5 \mathrm{hr}$ post feeding of pigs previously fasted for 1 day.

hr of the experimental period. The mean serum $\mathrm{Cu}$ concentration for all treatments can be seen in figure 2 . Serum $\mathrm{Cu}$ concentrations were 2.47 $\mathrm{mcg} / \mathrm{ml}$ initially, $2.29 \mathrm{mcg} / \mathrm{ml}$ at $2.0 \mathrm{hr}, 2.57$ $\mathrm{mcg} / \mathrm{ml}$ at $3.0 \mathrm{hr}$ and $2.44 \mathrm{mcg} / \mathrm{ml}$ at $7.5 \mathrm{hr}$ post feeding.

The animal $x$ time interaction for differences in serum $\mathrm{Cu}$ concentration was significant $(\mathrm{P}<$ .01). Differences in serum $\mathrm{Cu}$ concentration due to day of sampling of pigs were not significant.

As indicated earlier, at periodic intervals, blood samples were collected and hemoglobin levels and PCV determined. Initial hemoglobin levels and PCV were $11.6 \mathrm{~g} / 100 \mathrm{mls}$ and $34.3 \%$, respectively, while final hemoglobin and PCV were $11.3 \mathrm{~g} / 100 \mathrm{mls}$ and $34.6 \%$. These values agree closely with those reported by Bunch et al. (1965), Combs et al. (1966) and Kline et al., (1972). Since normal hemoglobin levels and PCV were observed throughout the duration of the study, it appears that frequent blood sampling per se $(5 \mathrm{ml} / \mathrm{pig} /$ time interval $)$ had no particular influence on the blood composition of the animals.

Buescher et al. (1961) found no differences in plasma $\mathrm{Cu}$ concentration of barrows orally dosed with ${ }^{64} \mathrm{Cu}$ labelled cupric carbonate, cupric oxide or cupric sulfate. Similarly, no significant differences in serum $\mathrm{Cu}$ concentration were observed in the research reported herein where $\mathrm{Cu}$ was fed in the inorganic or pre-chelated form or in the presence of EDTA in a 1:1 molar ratio with $\mathrm{Cu}$. Thus, it appears that chelation has little influence on the uptake of $\mathrm{Cu}$ by swine at the level of $\mathrm{Cu}$ fed or by the chelating agent used in this study.

Although no significant treatment differences in serum $\mathrm{Cu}$ concentration were observed, serum $\mathrm{Cu}$ concentrations were significantly ( $\mathbf{P}$ $<.05$ ) affected by sampling time. As the animals began consuming the diet, they also began drinking water (water analyzed 1.3 $\mathrm{mcg} / \mathrm{ml} \mathrm{Cu}$ ). As indicated earlier, the serum $\mathrm{Cu}$ concentration decreased rather consistently across treatments during the first $2.0 \mathrm{hr}$, peaked at $3.0 \mathrm{hr}$ and plateaued near initial levels for the remaining experimental period (see figure 1 and 2). It appeared that upon consumption of the diet, either the serum $\mathrm{Cu}$ concentration dropped or the liquid phase of blood increased. Copper ions may be involved in some enzyme functions and are transported and secreted into the digestive tract or upon consumption of the feed and water, total blood volume increased.

Sampling time is important, since different serum $\mathrm{Cu}$ concentrations were obtained depending upon when the samples were taken. The results may help explain why blood studies have not shown significant treatment differences. The time of sampling following consumption of a diet will greatly influence serum $\mathrm{Cu}$ concentration. This factor will need to be accounted for when planning experiments involving blood sampling.

\section{Literature Cited}

Barber, R. S., R. Braude and K. G. Mitchell. 1955. Antibiotic and copper supplements for fattening pigs. Brit. J. Nutr. 9:378.

Braude, R. 1965. Copper as a growth stimulant in pigs (Cuprum pro pecunia). Symposium on copper's role in plant and animal life. Vienna, Austria.

Buescher, R. G., S. A. Griffin and M. C. Bell. 1961. Copper availability to swine from $\mathrm{Cu}^{64}$ labelled inorganic compounds. J. Anim. Sci. 20:529.

Bunch, R. J., J. T. McCall, V. C. Speer and V. W. Hays. 1965. Copper supplementation for weaning pigs. J. Anim. Sci. 24:995.

Castell, A. G. and J. P. Bowland. 1968. Supplemental copper for swine: Growth, digestibility and carcass measurements. Can. J. Anim. Sci. 48:403.

Combs, G. E., C. B. Ammerman, R. L. Shirley and H. D. Wallace. 1966. Effect of source and level of dietary protein on pigs fed high-copper rations. $J$. Anim. Sci. 25:613. 
Davis, P. N., L. C. Norris and F. H. Kratzer. 1962. Interference of soybean proteins with the utilization of trace minerals. J. Nutr. 77:217.

DeGoey, L. W., R. C. Wahlstrom and R. J. Emerick. 1971. Studies of high level copper supplementation to rations for growing swine. J. Anim. Sci. 33:52

Gipp, W. F., W. G. Pond, J. Tasker, D. Van Campen, L. Krook and W. J. Visek. 1973. Influence of dietary copper on weight gain, hematology and liver copper and iron storage of young pigs. J. Nutr. 103:713.

Hawbaker, J. A., V. C. Speer, V. W. Hays and D. V. Catron. 1961. Effect of copper sulfate and other chemotherapeutics in growing swine rations. J. Anim. Sci. 20:163.

Kline, R. D., V. W. Hays and G. L. Cromwell. 1971. Effect of copper, molybdenum and sulfate on performance, hematology and copper stores of pigs and lambs. J. Anim. Sci. 33:771.

Kline, R. D., V. W. Hays and G. L. Cromwell. 1972. Related effects of copper, zinc and iron on performance, hematology and copper stores of pigs and lambs. J. Anim. Sci. 34:393.
Merck Manual (11th Ed.). 1966. The Merck Manual of Diagnosis and Therapy, Merck Division of Research.

N.R.C. 42 Committee on Swine Nutrition. 1970. Supplemental copper and vitamin E for G-F swine. J. Anim. Sci. 31:1025. (Abstr.).

Olson, A. D. and W. B. Hamlin. 1968. Serum copper and zinc by at omic absorption spectrophotometry. Atomic Absorption News Letter. Vol. 7 No. 4.

Perkin-Elmer. 1971. Analytical methods for atomic absorption spectrophotometry. Perkin-Elmer, Norwalk, Conn

Steele, R. G. D. and J. H. Torrie. 1960. Principles and Procedures of Statistics. McGraw-Hill Co., New York.

Wallace, H. D. 1967. High level copper in swine feeding. A review of research in the United States. International Copper Research Association, Inc., New York.

Zimmerman, D. R., B. Lantz, C. Naber, P. Koonsman and T. Stahly. 1973. A venous cannulation technique for obtaining blood from unstressed swine. J. Anim. Sci. 37:334. (Abstr.). 